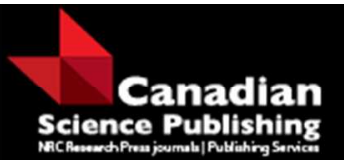

Canadian Journal of Forest Research Revue canadienne de recherche forestière

\title{
Does Gender Diversity in Forest Sector Companies Matter?
}

\begin{tabular}{|r|l|}
\hline Journal: & Canadian Journal of Forest Research \\
\hline Manuscript ID & cjfr-2016-0040.R2 \\
\hline Manuscript Type: & Article \\
\hline Complete List of Authors: & $\begin{array}{l}\text { Hansen, Eric; Oregon State University } \\
\text { Conroy, Kendall; Oregon State University College of Forestry } \\
\text { Toppinen, Anne; University of Helsinki } \\
\text { Bull, Lyndall; Lynea Advisory } \\
\text { Kutnar, Andreja; Univerza na Primorskem } \\
\text { panwar, Rajat; Appalachian State University, Walker College of Business }\end{array}$ \\
\hline Keyword: & $\begin{array}{l}\text { gender diversity, diversity, financial performance, human resources } \\
\text { management, workforce diversity }\end{array}$ \\
\hline &
\end{tabular}

\section{SCHOLARONE ${ }^{m}$ \\ Manuscripts}




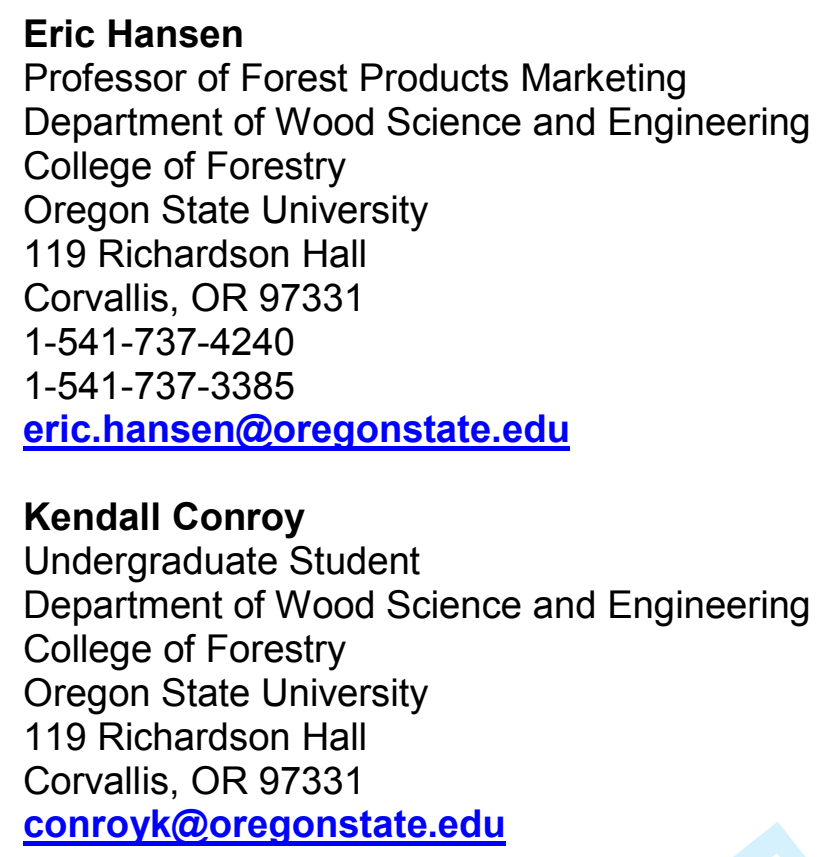




\section{Abstract}

52 The extant literature concerned with enhancing competitiveness of forest sector companies has

53 focused on phenomena rather than people who would drive those phenomena. Even generally,

54 human resource management research is sparse in the forest sector literature, despite well

55 documented knowledge that companies succeed more because of their people than any other

56 factor. This article brings human resource issues to the core conversation in forest sector

57 competitiveness research. Specifically, we focus on the link between gender diversity in top

58 leadership and firm financial performance and suggest pathways to improve workforce diversity.

59 The timing of our study is fortuitous as the graying workforce in the sector will create space for a

60 new generation of leaders. Our argument is that diversity issues should be more proactively

61 addressed in forest sector workforce recruitment not just because it is the right thing to do, but

62 because it also has an underlying business case. This is an exploratory study, which is a first

63 step in paving the way for future work on diversity management among forest sector companies.

64 Our findings suggest that more gender diverse top management teams are associated with

65 higher financial performance, but the level of gender diversity in boards of directors has no

66 association with financial performance.

67

68 Key Words: diversity, financial performance, forest industry, gender diversity, human resources

69 management, workforce diversity

70

71 
73 Until the beginning of the current century, the global forest industry was characterized by a

74 relatively stable competitive context - markets were generally growing, buyer-supplier contracts

75 were long term, and even leading companies were still internationalizing (Ojala et al. 2007). In

76 short, competition among forest sector companies was low to moderate. But those times have

77 disappeared (Hansen et al. 2014a). The emergence of numerous raw material sources through

78 large scale plantations, myriad low cost processing centres, threats from substitute products,

79 and turbulent economic, technological, ideological, and demographic patterns have pushed the

80 forest industry to a point where it must find new ways to remain relevant (Kozak 2014).

82 How will this transition happen? Who will make it happen? The extant literature addressing such

83 issues has mostly focused on phenomena - innovation management (Hansen et al, 2014b), sustainability management (Toppinen et al. 2016), new technology adoption (Panwar et al. 2012) —but people within companies who would drive those phenomena have seen surprisingly little discussion (for exception, see Kozak 2014). As such, human resource management research is generally sparse in the forest sector literature, despite well documented knowledge that companies succeed more because of their people than any other factor (Laursen and Foss 2003). We aim to take a step in bridging that gap in the forest sector literature. Our timing for this study is fortuitous because of an impending generational transition of a graying forest sector workforce that is reaching retirement age and creating space for a new generation of leaders.

92 We argue that this oncoming wave of retirements presents a novel and significant opportunity 93 for the forest sector to develop visionary policies and strategies to bring in a talented, creative 94 workforce that can effectively steer the forest industry into an unpredictable future.

96 To be sure, a large-scale human resource transformation in the industry is not a trivial topic that 97 can be effectively summarized in a single paper. Here, we specifically focus on leadership 
diversity, which is one of the basic tenets of effective workforce development and a recurring

99 100

101 102 103 104 105 106 107 108 109 110 issue for the forest sector that typically lacks diversity in its workforce (BLS 2014).

There are multiple motivations to pursue workforce diversity; some legislated, others based on ethical considerations, and yet others driven by the business case for doing so. Evidence suggests that more diversity pays off through increased creativity (Campbell and Minguez-Vera 2008, Green et al. 2008), openness to change (Green et al. 2008), and innovativeness (Bantel and Jackson 1989, Campbell and Minguez-Vera 2008) as well as enhanced company financial performance or value (Perryman et al. 2016, Isidro and Sobral 2015, Reguera-Alvarado et al. 2015,Giffi and McNelly 2013, Campbell and Minguez-Vera 2008). Despite the fact that the general literature contains myriad studies investigating the diversity-performance relationship and there are sector specific studies for industries such as automotive, we were unable to uncover any peer reviewed studies covering the diversity-performance relationship in the forest products manufacturing sector. Given this dramatic gap in the literature, the present study is an initial foray into understanding the phenomenon within the forest sector. We focus our efforts specifically on gender diversity within the boards of directors and corporate executive teams (hereafter referred to as top management teams or TMTs) of large forest sector companies in North America, Europe and Oceania. Specifically, our objectives are as follows:

1. Identify the relationship between gender diversity at board and executive levels and the financial performance of forest sector companies

2. Propose a path forward for industry to increase its workforce diversity

3. Stimulate further research to promote workforce diversity in the forest sector

In the remainder of the paper, we first provide a theoretical background regarding gender diversity and its potential link with company performance. This is followed by a description of the methods employed in the study, results, and discussion. We then provide insights regarding 
124 potential paths forward. Finally, because the topic of gender diversity is novel in the context of 125 forest products industry, we emphasize directions for the future research needed to better 126 understand how diversity may, or may not, benefit forest sector companies.

127

\section{Theoretical Background}

Although progress has been made in recent decades to diversify the leadership of corporate America, the current status of gender diversity remains poor. As of 2012, 20\% of Fortune 100 board seats belonged to women. This is up only six percent over the previous six years (Anonymous 2013). In the manufacturing sector the situation is even worse where females occupy only just over $16 \%$ of board seats (Giffi and McNelly 2013). The situation is no better in non-board executive positions where just over $11 \%$ of officers in 2012 were women.

The question whether diversity enhances company performance has been debated by management scholars for decades (e.g., Erhardt et al. 2003) as there are arguments both in favor for and against it. There are many reasons that a diverse workforce may not produce positive results (Jayne and Dipboye 2004, Kochan et al. 2003). For example, Erhardt et al. (2003) aptly summarize this duality that diversity, on the on hand, can increase decision-making capacity but at the same time increase within-group conflict. Results from research investigating the economic impacts of diversity are decidedly mixed and are said to be so because of many differences among studies, missing explanatory variables, etc. (Adams et al. 2015). Very recent work finds a positive relationship between board diversity and financial performance (Perryman et al. 2016, Reguera-Alvarado et al. 2015). In a large-scale international study of 22,000 companies from 91 countries, Noland et al. (2016) found a positive association between female share of TMTs and firm performance in data for 2014, but no effect of board membership or board gender quotas on firm performance. Still, even meta-analytic studies come to conflicting findings (Post and Byron 2015, Pletzer et al. 2015). Clearly the 
150 impacts of diversity are complex and likely also context dependent (Pletzer et al. 2015, Adams 151 et al. 2015).

152

153 There are a number of theories (e.g., agency theory) that have been used to explain the impact 154 of boardroom and TMT diversity on company performance (Reguera-Alvarado et al. 2015).

155 Ultimately, group dynamics is the key concept and the principles of how groups relate to 156 minority members can be used to suggest relationships between gender diversity and the 157 effectiveness of the decision-making by those teams. At the most basic level, more diverse 158 thinking leads to better decisions. Increasing diversity is said to introduce a number of factors 159 that can contribute to enhanced group performance and following on, company performance.

160 The foundational element of increased diversity is cognitive diversity or differential thinking that 161 results from introducing different knowledge bases, experience bases, thinking styles, etc. As 162 described by Perryman et al. (2016, p. 2), "Having top managers with varying outlooks and 163 interpretations is critical to understanding complex environments...the same reality can be 164 perceived by diverse managers in different but complimentary ways."

166 Research shows myriad positive implications of increased group diversity. Examples of positive 167 implications of gender diversity include: improved group decision-making (Erhardt et al. 2003), 168 improved managerial task performance (Dezsö and Ross 2012), enhanced legitimacy (Perrault 169 2015) introduction of new ideas and skills (Reguera-Alvarado et al. 2015) more innovative and 170 creative decision-making (Bantel and Jackson 1989), better reflection of customer and 171 stakeholder needs (Konrad et al. 2008), deeper and more extensive consideration of issues 172 (Post and Byron 2015), and increased social capital and social responsibility (Bear et al. 2010). 173 Specific to the impact of women on teams, they tend to reduce company risk taking and are 174 associated with greater company performance (Perryman et al. 2016) despite higher turnover 175 and absenteeism (Campbell and Minguez 2008). In addition, those companies that pursue a 
176 more gender diverse leadership team and workforce will be tapping into a highly educated and

177 skilled talent pool since, for example in the US, the greater proportion of college degrees are

178 now earned by females (Catalyst 2004). These various elements should contribute to enhanced

179 company performance. Based on the foregoing discussion, we hypothesize:

H1: Companies with a larger share of female board members have higher financial performance.

H2: Companies with a larger share of female top management team members have higher financial performance.

\section{Methods}

\section{Population and Sample}

We use secondary data for this study gleaned from Web sites and public documents of the target companies. As a sample frame we utilize the PricewaterhouseCoopers (PWC 2013) global top 100 pulp paper and packaging companies. PricewaterhouseCoopers conducts an

192 annual study of the top 100 companies in the sector and provides various data about the companies. The ranking 2013 PWC ranking (for year 2012) is used in this study.

After an initial exploration of companies from around the globe, we found it infeasible to access data in some countries/languages. For example, Japanese companies seldom publish pictures of their boards or TMTs and the research team did not possess the necessary expertise to infer gender based on names. Accordingly, we chose to limit the target companies to those in North America, Europe, and Oceania. This resulted in an initial sample of 65 companies. Between

200 publishing of the PWC top 100 list and our data collection, mergers or purchases eliminated 201 multiple companies from the study. The final list of 54 companies is shown in Table 1. 


\section{Data and Analysis}

204 The following data comes from company web sites and annual reports and information provider 205 YCHARTS:

- Total members of the board of directors

- Total female members of the board of directors

- Total members of the TMT

- Total female members of the TMT

- $\quad$ Size measured by annual sales

- World region of company headquarters (Europe, North America, or Oceania)

- Product area representing the largest proportion of sales (pulp, paper \& packaging or wood)

214 We use earnings before interest, taxes, depreciation, and amortization margin (EBITDA margin)

215 as a metric for company performance. Given the regional representation of companies and 216 inconsistencies in reporting, EBITDA margin is the most consistently available and/or reported

217 value across all companies. Our primary source for EBITDA margin is an online provider,

218 YCHARTS (ycharts.com). In total, the value for EBITDA margin comes from YCHARTS for 34 of

219 the companies and from company annual reports for the remaining companies.

221 Data were collected between February and November of 2015 and generally represents 2014 222 company results, although some companies may operate on a fiscal rather than calendar year.

223 Because of the variance in corporate structures among companies in the sample, two

224 researchers collected data regarding the boards of directors and TMTs. The findings of the two 225 researchers were compared and where differences existed a third member of the research team 
226 helped make a final decision. Initial consensus between the two data collection efforts was quite 227 high (84\%), after adjudication it was $100 \%$.

In pre-checking the financial performance data, three companies with either negative EBITDA margin value (Resolute Forest Products, PaperlinX) or lack of information (Billerud) were excluded, resulting in the final sample of 51 companies in the regression models. We use correlations and OLS regression to test relationships between company performance and the 233 share of females in top management teams and in the boards of directors. For checking 234 robustness of the relationship at this preliminary stage of analysis, we could use as control 235 variables only firm size, product line and headquarter location. Specifically, EBITDA is the dependent variable in our regression models and the independent variables include: proportion

237 of females on either Board or TMT, sales (control), dummy for companies with three or more females on Board or TMT, dummy for product line (control), and dummy for region in which the company is headquartered (control). Data for sales and financial performance are transformed in natural logs in order to improve distributional properties of data. To ensure that there is no residual heteroscedasticity, the White test is used along with an F-test for overall model significance in the least squares estimation process.

\section{Results}

246 Of the 51 companies in our final database, the largest set is headquartered in the US (15),

247 followed by the Canada (10), and Sweden (5). The companies have 499 members of their 248 boards of directors and 414 members of their TMTs. Overall, female members represent $15.9 \%$ 249 of boards of directors and $15.8 \%$ of TMTs. The largest number of female board members for 250 any one company is five ( $42 \%$ or 5 of 12$)$ while the largest number for TMTs is six $(50 \%)$. With 251 respect to the TMTs, the most common roles for women are in the area of human resources, 
252 followed by divisional president, finance, and communications (Table 2). In total, three (6\%) of

253 the companies had a female CEO. Kimberly Clark is the only US-based forest sector company

254 that Catalyst identifies as having $25 \%$ or more women executives (Catalyst 2013). Overall, there

255 were nine (18\%) companies with no females on the board of directors, $21(41 \%)$ companies with

256 no females on the TMT, and three (6\%) companies with no females on either (all from Europe).

257 Overall, $85 \%$ of European companies had at least one female member of the board. However,

258 this proportion was much lower for TMTs of European companies (38\%) and may reflect EU

259 legislation targeting better balance on boards of directors'. With respect to individual countries,

260 the only company from Poland has no females in board or TMT positions while two of four

261 companies from Portugal and four of ten from Canada are in the same situation. Figures 1 and

2622 provide a picture of female representation by company.

263

264 According to results from correlation analysis (Table 3), the share of female board membership

265 is positively correlated with size of the company as measured by sales. Female share of TMTs

266 is also positively correlated with financial performance as measured by EBITDA margin. In

267 addition, female shares in TMTs and boards are also correlated positively, which is to be

268 expected, but the level of correlation is only moderate (0.31). Based on this, the risk of

269 multicollinearity between sales and female representation in boards or TMTs is unlikely to be a

270 problem in the models. The finding that female shares of TMT and board memberships are

271 moderately correlated is in line with Noland et al.'s (2016, p. 9) comment that, "a more gender-

272 balanced board might show greater interest in encouraging a more balanced executive team.

273 Certain firm and national characteristics are robustly correlated with the presence of women not

274 only in boards but also in upper management more generally."

275

276 It is also interesting to note substantial differences between companies listed in Figures 1 and 2

277 with highest shares of females in their board and TMTs. In addition, among the top 10 
278 companies in the PWC list, only Kimberly-Clark and Stora Enso appear among the companies 279 with highest share of females in top management. Three companies exist with at least half 280 female TMT members (Sveaskog, Weyerhaeuser and Heinzel Holding), whereas only one 281 Swedish company (Sveaskog), crosses the 40\% threshold for females in board membership.

We estimate separate models for share of female TMTs and board memberships, and the results are reported in Tables 4 and 5, respectively. In addition to female TMT share (or share in board) the models include sales as well as dummy variables for companies with number of

286 females exceeding two (executive dummy), product line (pulp, paper packaging or wood

287 products), and region of headquarters (Europe, North America). Model 1 is the most

288 parsimonious, including only the effect of female share in TMT. Model specification 2 includes

289 sales as a control variable, and Model specification 3 includes all variables of interest. This

290 approach is deemed sufficient as we are not interested in the estimation of elasticity values per

291 se but whether significant relationship can be identified between firm performance and gender 292 diversity in the first place.

294 According to Model specifications 1-3 for TMT membership share, there is a positive effect from 295 increased female proportion on financial performance, whereas the effects of company size, 296 region or product line are insignificant. The executive dummy variable for a threshold of more 297 than two female members is also non-significant. All models have modest explanatory power, 298 but the more parsimonious 1 and 2 are nevertheless significant according to F-tests indicating 299 robustness of this finding and none of the models suffer from residual heteroscedasticity 300 according to White-tests. 
302 Results for Model specifications 4-6 for female board membership are generally non-significant, 303 but are presented here for comparison purposes. According to F-tests, none of the models are 304 significant.

305

\section{Discussion}

307

308

According to our regression models, there is only a weak positive effect from female TMT share on corporate financial performance and there is no effect from the share of board membership, as also indicated by the insignificant bivariate correlation. The dummy variable capturing a threshold of more than two females in either one of the teams is non-significant. Furthermore, no differences are evident based on region of headquarters or primary product line. In this respect the global forest industry is rather homogenous in terms of financial performance, a finding similar to that of Zhang and Toppinen (2011) from the perspective of industry internationalization.

The weak effect of gender diversity on performance is, perhaps, not surprising given the extremely low representation of females within the companies represented in this study. For example, $43(84 \%)$ of the companies have two or fewer female representatives on their TMTs. This may reflect what is often referred to in the literature as tokenism (Schwab et al. 2015). There is evidence to suggest that the real impact of gender diversity on groups is when there are three or more females (approximately one in seven of the companies in our database). Konrad et al. (2008) refer to three as a magic number where female representation is no longer a token and the diverse views of female members become genuinely integrated into team discussions. For most of the companies in this study, it may be that the diversity present in the teams simply has no, or limited voice. 
327 Gender is essentially a proxy for different experiences, ways of thinking, and values. The 328 masculine industry leadership structure could be reflected in its dominant logic, the concept 329 often used in conjunction with too strong lock-in and perceived difficulty to diversify existing 330 business models and changing of the cultural mind-set (see Pralahad and Bettis 1986, Prahalad 331 2004). Given the small proportion of females in leadership positions in this study, an alternative 332 explanation is that to get where they are today, women have largely needed to conform to the 333 prevailing male-dominated culture. If this is, in fact the case, higher level decision-making in the 334 study companies does not benefit from significantly different thinking and values.

With respect to the TMTs in our sample, females were often in positions related to human resources and communications and these positions may be less central to strategy making than other positions on the TMT. Accordingly, these individuals may be less well-placed to impact strategic decisions and, therefore, company performance.

An alternative theoretical lens through which to view the diversity conundrum is slack resources theory. In the trying times of the last decade, large forest sector companies, in general, have not experienced good financial performance (PWC 2013). Accordingly, they may lack the slack resources necessary to build a more diverse leadership team. Given the global financial crisis, historically low profitability, and a generally harsh operating environment, the focus could well have been more on staying afloat than on diversifying the board or TMT. In the end, women in 347 leadership for much of the forest sector is a new phenomenon. marketplace understanding via a better match with employees and potential customers. In other words, when the diversity of the board better reflects the diversity of the marketplace, it is able 352 to perform better in that market. In general, past research shows a forest sector that deserves 
353 further development with respect to market and customer orientation (Han and Hansen 2016,

354 Hansen and Juslin 2006, Cohen and Kozak 2002). Increased diversity on forest sector company

355 boards and TMTs may be a way to further develop market and customer orientation as well as

356 innovation (Hansen and Breed 2016). Others show that the percentage of females on boards is

357 related to voluntary sustainability related actions, another sign of being in tune with the

358 marketplace (Ben-Amar et al. 2015).

360 Given the intuitive sense of positive performance impacts of increased diversity, mixed findings

361 in the literature, and the suggestions that the relationship is contextual, one can hypothesize

362 that the lack of positive findings may be the result of poor implementation of group processes to

363 capitalize on the potential of diversity. For example, the potential positive contribution of

364 diversity to performance may be mitigated by the CEO and how he or she incorporates diverse

365 views into decision making (Kakabadse et al. 2015, Pletzer et al. 2015). Webber and Donahue

366 (2001) advocate for team development that would be more effective in drawing out different

367 skills and knowledge that could then be applied to the problems at hand.

368

369 Finally, it is important to acknowledge that there are many factors impacting company

370 profitability. These may have, as pointed out by one anonymous reviewer, a greater impact on

371 firm performance than gender diversity. Still, given that we found a relationship between gender

372 diversity and firm performance among these many factors shows the potentially valuable

373 insights from further work in this area.

A Path Forward

376 The forest sector is not alone in its lack of diversity. In the US manufacturing sector, women

377 represent only about $25 \%$ of the total workforce compared to nearly $50 \%$ in the general

378 workforce (Giffi and McNelly 2013). In a report focused on the automotive industry, Wachol et 
379 al. (2010 p. 8) suggest that, "For many automotive companies, recruiting female talent is a little 380 like a dog chasing a car: What would the dog do if it caught one?" The same authors go on to 381 outline the top five most important attributes of a job from women in the automotive industry: 382 Challenging assignments, income/pay, work-life balance, working relationships, and promotion 383 opportunities. We expect that this list is similar across most industries and countries, so it 384 provides a starting point for companies that wish to be more strategic about their recruitment 385 and retention efforts. However, while such lists are useful and there is benefit to understanding 386 the drivers and incentives to attract and retain female talent, a better approach would be to 387 manage the workplace in a more holistic manner. For example, using the list developed by 388 Wachol et al (2010) outlined above, it would be most surprising if all employees, that is men and 389 women, were not looking for the same attractive attributes in their workplace.

391 Perhaps the best example of the differing attitudes of workplaces towards the two genders 392 exists after a couple start a family. While there are obvious improvements that can still be made, 393 there is a general acceptance and efforts made by employers to offer female employees 394 adjusted working conditions, be it to work flexibly or part time, after the birth of a child. For 395 example, in Australia, the majority of working mothers with children aged 11 or younger do not 396 work in the traditional 9-5 sense (Baxter 2013). Their working conditions tend to dramatically 397 change after the birth of a child to incorporate part time, flexible hours, working from home or 398 shift work. Such a dramatic shift away from the traditional work day, typically at an age where 399 they are hitting the prime of their career, is likely to affect opportunities for promotion to the TMT 400 or board level. Conversely, for men, the likelihood that they will change their approach to work is 401 much less. Most typically this is a change to flexible hours - not part time as women often do. 402 (Baxter 2013). The focus for future research and workplace policies should therefore not solely 403 be on what women need in order to simply stay in the workplace, but rather what the workplace 
404

405

406

407

408

409

410

411

412

413

414 2012).

415

416

417

418

419

420

421

422

423

424 To be realistic, the pool of females qualified for leadership and board positions in the sector is

425 small, especially relative to males. Even for the proactive and innovative forest sector company,

426 it may be highly challenging to identify and attract candidates. Therefore, it is imperative that,

427 regardless of ethical or business case motivations, that companies approach this issue with a

428 well-tuned, long-term strategy. The strategy should encompass recruiting young employees and 
429 promoting from within, attracting outside talent into traditional positions, and utilizing talent that 430 is increasingly operating in a non-traditional manner through project work.

431 1. Systematically recruiting and developing internal talent is an essential component of any

2. The strategy should also include recruiting talent from outside the organization since long-term diversification strategy. Companies should plan for effective recruiting of young females and careful mentoring of these individuals so that they are well-placed to climb the corporate ladder. experience outside the company provides its own, additional diversity in thinking. Forest sector companies often proudly emphasize their promotion from within policies. While these policies can clearly be a positive element of company culture, they should not exclude the richness of experience and thinking that is possible from incorporating outside perspectives.

3. Another important element of the strategy is to actively engage with the growing number of people, typically women, who work on a project basis. Such candidates typically have the capacity to offer their diverse experience in an efficient and effective manner.

4. Finally, companies should promote a range of working approaches, to both male and female employees that allows them to stay actively engaged in the workplace when one or both parents may need alternative working conditions to manage the needs of a young family. Such flexibility will help ensure employees have the opportunity to retain and enhance their skills while also decreasing the likelihood of losing talent that the employer or industry more generally has invested in.

\footnotetext{
454 include more companies and time series data. This could, for example, allow identification of
} 
dynamic effects that were impossible to test for with our data and could also address causality of the relationship, especially since previous research has indicated persistence of profits in this

457 same reference group of forest industry companies (Laaksonen-Craig and Toppinen 2008).

458 There are many indices of company performance and value that should be considered in future, 459 similar studies. Finally, diversity is not a singularly gendered issue. Ethnicity, age, sexual 460 orientation, and beliefs all contribute to diverse groups and should be considered in future 461 studies. Given the retiring workforce in the forest sector, age diversity (e.g., Ali et al. 2014) may 462 be especially important to investigate.

464 Another pertinent question is about how much diversity is needed to make a difference? Are 465 there thresholds or levels of diversity below or beyond which the diversity-performance link might not work? Previous research alludes to this possibility as higher levels of diversity can 467 increase group conflict and decrease group communication (Campbell and Minguez-Vera 468 2008), create factions within teams (Adams et al. 2015), increase group turnover due to increased conflict and decreased communication (Bantel and Jackson 1989), and ultimately

470 result in lower member satisfaction (Milliken and Martins 1996). Proposals for striking a balance

471 between too little and too much diversity are also put forward (Campbell and Minguez-Vera

472 2008, Webber and Donahue 2001), but what is too little or too much remains contested. We 473 believe that this balance is ultimately contextually-rooted and research can help forest sector 474 companies identify and achieve the right balance.

475

476 Future work should focus on companies that have moved beyond the two female threshold and 477 identify the outcomes and lessons learned from these processes. These insights would be 478 invaluable to companies that wish to further diversify their teams and reap the potential financial 479 rewards of those actions. Also, an in-depth understanding of how current female executives and 480 board members in the industry view the sector they work in, how they have navigated their 
481 careers in a male-dominated workplace, and advice they would give young females entering the 482 industry would be a significant contribution.

483

484 
486 The authors acknowledge Smiljana Škvarc for support with data collection. Furthermore, Anne 487 Toppinen acknowledges financial support from the Academy of Finland (\#Grant 278363) and 488 Andreja Kutnar is pleased to acknowledge the support of European Commission for funding the 489 project InnoRenew CoE (\#Grant Agreement 664331) under the Horizon2020 Widespread-2015 490 program, and infrastructure program IP-0035.

491

492 
494 Adams, R. B., Haan, J., Terjesen, S., \& Ees, H. 2015. Board diversity: Moving the field forward. 495 Corporate Governance: An Int Rev. 23(2): 77-82.

497 Ali, M., Ng, Y. L., \& Kulik, C. T. (2014). Board age and gender diversity: A test of competing 498 linear and curvilinear predictions. Journal of Business Ethics, 125(3), 497-512.

Anonymous. 2013. Missing Pieces: Women and Minorities on Fortune 500 Boards. Alliance for 501 Board Diversity. 2012 ABD Census. 18 pp.

502

503

Bantel, K. A., \& Jackson, S. E. 1989. Top management and innovations in banking: does the 504 composition of the top team make a difference? Strat Mgmt J. 10: 107-124.

505

506

Baxter, J. 2013. Parents Working Out Work. Australian Family Trends No. 1, Australian Institute

507

of Family Studies. Available at: https://aifs.gov.au/publications/parents-working-out-work.

508

509

Bear, S., Rahman, N., \& Post, C. 2010. The impact of board diversity and gender composition

510 on corporate social responsibility and firm reputation. J of Bus Ethics. 97(2): 207-221.

511

512 Ben-Amar, W., Chang, M., \& Mcllkenny, P. (2015). Board Gender Diversity and Corporate

513 Response to Sustainability Initiatives: Evidence from the Carbon Disclosure Project. Journal of 514 Business Ethics, 1-15.

515

BLS. 2014. Labor Force Statistics from the Current Population Survey.

517 http://www.bls.gov/cps/cpsaat18.htm. Last Accessed on August 16, 2014. 
519 Campbell, K., \& Mínguez-Vera, A. 2008. Gender diversity in the boardroom and firm financial 520 performance. J of Bus Ethics. 83(3): 435-451.

521

522 Catalyst. 2013. 2013 Catalyst Census: Fortune 500 Women Board Directors. Catalyst. New 523 York, New York. 4 pp.

524

525 Catalyst. 2004. The Bottom Line: Connecting Corporate Performance and Gender Diversity.

526 Catalyst. New York, New York. 28 pp.

527

528 Cohen, D. H. \& Kozak, R. A. 2002. Research and technology: Market-driven innovation in the 529 twenty-first century, The For Chronicle. 78(1): 108-111.

530 Dezsö, C. L., \& Ross, D. G. 2012. Does female representation in top management improve firm 531 performance? A panel data investigation. Strat Mgmt J. 33(9): 1072-1089.

533 Erhardt, N. L., Werbel, J. D., \& Shrader, C. B. 2003. Board of director diversity and firm financial 534 performance. Corporate governance: An Int Rev. 11(2): 102-111.

535

536 Giffi, C.A., and J. McNelly. 2013. Untapped Resource. How Manufacturers Can Attract, Retain, 537 and Advance Talented Women. Deloitte Development LLC. 14 pp.

538

539 Green, K.A., M. Lopez, A. Wysocki, and K. Kepner. 2008. Diversity in the Workplace: Benefits, 540 Challenges, and the Required Managerial Tools. University of Florida, IFAS Extension HR022. 3 $541 \mathrm{pp}$. 
543 Hansen, E. and B. Breede. 2016. Practical Experience in Forest Sector Innovation: The Case of 544 Cox Industries, Inc. BioProducts Business. (In Review).

545

546 Hansen, E., Panwar, R., \& Vlosky, R. 2014a. Understanding and managing change in the global

547 forest sector. P. 3-13. Editors: Hansen, E., Panwar, R. \& Vlosky, R. The Global Forest Sector:

548 Changes, Practices, and Prospects. CRC Press. Boca Raton, Florida. 462 pp.

549

550 Hansen, E., Nybakk, E., \& Panwar, R. 2014b. Innovation insights from North American forest 551 sector research: a literature review. Forests, 5(6), 1341-1355.

552

553 Hansen, E., Juslin, H., \& Knowles, C. 2007. Innovativeness in the global forest products

554 industry: exploring new insights. Can J of For Res. 37(8): 1324-1335.

555

556 Han, X. and E. Hansen. 2015. Marketing Sophistication in Private U.S. Sawmilling Companies.

557 Can J of For Res. (In Press).

558

559 Isidro, H., \& Sobral, M. 2015. The Effects of Women on Corporate Boards on Firm Value, 560 Financial Performance, and Ethical and Social Compliance. J of Bus Ethics. 132(1): 1-19.

562 Jayne, M.E. and Dipboye, R.L. 2004. Leveraging diversity to Improve Business Performance:

563 Research Findings and Recommendations for Organizations. Human Res Mgmt. 43(4):409-424.

Kakabadse, N. K., Figueira, C., Nicolopoulou, K., Hong Yang, J., Kakabadse, A. P., \& Özbilgin, M. F. 2015. Gender Diversity and Board Performance: Women's Experiences and Perspectives.

567 Human Res Mgmt. 54(2): 265-281. 
569 Kochan, T., Bezrukova, K., Ely, R., Jackson, S., Joshi, A., Jehn, K., Leonard, J., Levine, D., \&

570 Thomas, D. 2003. The Effects of Diversity on Business Performance: Report of the Diversity

571 Research Network. Human Res Mgmt. 42(1): 3-21.

572

573 Konrad, A. M., Kramer, V., \& Erkut, S. 2008. Critical Mass: The Impact of Three or More

574 Women on Corporate Boards. Org Dyn. 37(2): 145-164.

575

576 Kozak, R. A. 2014. What Now, Mr. Jones? Some Thoughts about Today's Forest Sector and

577 Tomorrow's Great Leap Forward. The Global Forest Sector: Changes, Practices, and

578 Prospects, 431.P. 431-445. Editors: Hansen, E., Panwar, R. \& Vlosky, R. The Global Forest

579 Sector: Changes, Practices, and Prospects. CRC Press. Boca Raton, Florida. 462 pp.

580

581 Laaksonen-Craig, S. \& Toppinen, A. 2008. Profit persistence in globalizing forest industry 582 companies. Int For Rev. 10(4): 608-618.

583

584 Laursen, K., \& Foss, N. J. 2003. New human resource management practices, 585 complementarities and the impact on innovation performance. Cambridge Journal of 586 Economics, 27(2), 243-263.

587

588 Milliken, F. J., \& Martins, L. L. 1996. Searching for common threads: Understanding the multiple 589 effects of diversity in organizational groups. Acad of Mgmt Rev. 21(2): 402-433.

590

591 Noland, M., Moran, T., \& Kotschwar, B. 2016. Is gender diversity profitable? Evidence from a 592 global survey. Peterson Institute for International Economics. Working Paper 16-3. Peterson 593 Institute for International Economics. Washington DC. 35 pp. 
595 Ojala, J., J. Lamberg, A. Ahola, \& A. Melander. 2007. The ephemera of success: strategy, 596 structure and performance in the forestry industries. In: The evolution of competitive strategies 597 in global forest industries: Comparative perspectives, ed., J. Lamberg, J. Näsi, J. Ojala, and P. 598 Sajasalo. World forests: Dordrecht: Springer.

600 Panwar, R., Vlosky, R., \& Hansen, E. 2012. Gaining competitive advantage in the new normal. 601 For Pro J, 62(6), 420-428.

602

603 Perrault, E. 2015. Why Does Board Gender Diversity Matter and How Do We Get There? The 604 Role of Shareholder Activism in Deinstitutionalizing Old Boys' Networks. J of Bus Ethics. 128(1): $605 \quad 149-165$.

606

607 Perryman, A. A., Fernando, G. D., \& Tripathy, A. 2016. Do gender differences persist? An 608 examination of gender diversity on firm performance, risk, and executive compensation. $\mathrm{J}$ of 609 Bus Res. 69(2): 579-586.

610

611 Pletzer, J. L., Nikolova, R., Kedzior, K. K., \& Voelpel, S. C. 2015. Does Gender Matter? Female 612 Representation on Corporate Boards and Firm Financial Performance-A Meta-Analysis. PloS 613 one. 10(6).

614

615 Post, C., \& Byron, K. 2014. Women on boards and firm financial performance: A meta-analysis.

616 Acad of Mgmt J. 58:5 1546-1571.

617

618 Prahalad, C.K. 2004. The Blinders of Dominant Logic? Long Range Planning. 37: 171-179 619 
620 Prahalad, C.K. \& Bettis R.A. 1986. The dominant logic: A new linkage between diversity and

621 performance. Strat Mgmt J. 7(6): 485-501.

622

623 PWC. 2013. Global Forest, Paper \& Packaging Industry Survey 2013 edition - survey of 2012 624 results. PricewaterhouseCoopers. 17 pp.

625 Reguera-Alvarado, N., de Fuentes, P., \& Laffarga, J. 2015. Does Board Gender Diversity

626 Influence Financial Performance? Evidence from Spain. J of Bus Ethics. 1-14.

627 Schwab, A., Werbel, J. D., Hofmann, H., \& Henriques, P. L. 2015. Managerial Gender Diversity 628 and Firm Performance An Integration of Different Theoretical Perspectives. Group \& 629 Organization Management, 1059601115588641.

630 Toppinen, A., Lähtinen, K., \& Holopainen, J. 2016. On corporate responsibility. In Forests, 631 Business, and Sustainability, R. Panwar, R. Kozak \& E. Hansen (Eds). 70-90. Routledge. New 632 York, New York. 213 pp.

633 Wachol, A., J. Benkarski, and C.A. Giffi. 2010. Women at the Wheel. Everything you need to 634 know—but were afraid to ask—about attracting, retaining, and advancing female executives in 635 the automotive industry. Doloitte Development LLC. 14pp.

636

637 Webber, S. S., \& Donahue, L. M. 2001. Impact of highly and less job-related diversity on work 638 group cohesion and performance: A meta-analysis. J of Mgmt. 27(2): 141-162.

639

640 Zhang, Y. \& Toppinen, A. 2011. Internationalization and financial performance in the global 641 forest industry. Int For Rev. 13(1): 1-10. 
643 Table 1: Companies in Sample, Including PWC Size Ranking in 2012 (PWC 2013)

\begin{tabular}{|c|c|c|c|c|c|}
\hline Rank & Company & Country & Rank & Company & Country \\
\hline 1 & International Paper & US & 52 & Portucel & Portugal \\
\hline 2 & Kimberly-Clark & US & 55 & Clearwater Paper & US \\
\hline 4 & UPM - Kymmene & Finland & 59 & Louisiana-Pacific & US \\
\hline 5 & Stora Enso & Finland & 60 & Sonae Industria & Portugal \\
\hline 7 & Svenska Cellulosa (SCA) & Sweden & 61 & Tembec & Canada \\
\hline 8 & Smurfit Kappa & Ireland & 63 & P H Glatfelter & US \\
\hline 10 & Mondi Group & UK & 66 & Billerud* & Sweden \\
\hline 11 & Metsaliitto & Finland & 71 & Heinzel Holding & Austria \\
\hline 13 & Weyerhaeuser & US & 72 & Moelven & Norway \\
\hline 15 & Domtar & Canada & 74 & KapStone Paper and Pkging & US \\
\hline 20 & Sequana Capital & France & 75 & Norbord & Canada \\
\hline 21 & Sonoco & US & 76 & Mercer International & Canada \\
\hline 23 & Resolute Forest Products* & Canada & 77 & ENCE & Spain \\
\hline 24 & Graphic Packaging & US & 78 & Catalyst & Canada \\
\hline 27 & PaperlinX* & Australia & 80 & Plum Creek Timber & US \\
\hline 28 & Cascades & Canada & 82 & Sveaskog & Sweden \\
\hline 33 & West Fraser Timber & Canada & 83 & EUROPAC & Spain \\
\hline 34 & Norske Skog & Norway & 84 & Western Forest Products & Canada \\
\hline 36 & Packaging Corp of America & US & 88 & Appleton Papers & US \\
\hline 37 & Boise Cascade & US & 89 & Interfor & Canada \\
\hline 38 & Canfor & Canada & 92 & Arctic Paper & Poland \\
\hline 39 & Lenzing & Austria & 93 & Schweitzer-Mauduit & US \\
\hline
\end{tabular}




\begin{tabular}{|c|l|l|c|l|l|}
\hline 41 & Holmen & Sweden & 94 & Corticeira Amorim & Portugal \\
\hline 43 & Mayr-Melnhof Karton & Austria & 96 & Altri & Portugal \\
\hline 44 & Sodra & Sweden & 97 & Setra Group & Sweden \\
\hline 49 & Ahlstrom & Finland & 98 & Reno De Medici & Italy \\
\hline 51 & Universal Forest Products & US & 100 & Groupe Gascogne & France \\
\hline
\end{tabular}

644

${ }^{*}$ companies eliminated at analysis stage

645 
646 Table 2: Breakdown of female executive team member positions

\begin{tabular}{|l|r|r|}
\hline Position & Number of & Percentage of total \\
& females & female executives \\
\hline Human Resources & 14 & $22 \%$ \\
\hline President of a Division of the Company & 9 & $14 \%$ \\
\hline CFO & 8 & $12 \%$ \\
\hline Communications & 7 & $8 \%$ \\
\hline Other & 27 & $38 \%$ \\
\hline TOTAL & 65 & \\
\hline
\end{tabular}

647

648 
650 Table 3: Bivariate correlations between variables

\begin{tabular}{|c|c|c|c|c|}
\hline Variables & EBITDAM & Sales & $\begin{array}{l}\text { Female share in } \\
\text { board }\end{array}$ & $\begin{array}{l}\text { Female share in } \\
\text { TMT }\end{array}$ \\
\hline EBITDAM & 1.00 & & & \\
\hline Sales & 0.11 & 1.00 & & \\
\hline Share in board & 0.10 & $0.29^{* *}$ & 1.00 & \\
\hline Share in TMT & 0.26 * & 0.23 & $0.31^{* *}$ & 1.00 \\
\hline
\end{tabular}

651

652

653 
654 Table 4: Impact on company performance (EBITDA margin) for TMT membership

\begin{tabular}{|c|c|c|c|}
\hline & Model 1 & Model 2 & Model 3 \\
\hline Intercept & $-2.52^{* *}(0.00)$ & $-5.78^{* *}(0.02)$ & $-6.90^{* *}(0.03)$ \\
\hline TMT share & $1.54^{\star *}(0.04)$ & $1.36^{*}(0.07)$ & $1.83^{*}(0.09)$ \\
\hline Sales & & $0.15(0.19)$ & $0.19(0.15)$ \\
\hline Executive dummy & & & $-0.31(0.55)$ \\
\hline Product line dummy & & & $0.03(0.92)$ \\
\hline Region dummy & & & $0.20(0.44)$ \\
\hline Adj. R2 & 0.06 & 0.07 & 0.03 \\
\hline F-test & $4.39^{* \star}(0.04)$ & $3.10^{* *}(0.05)$ & $1.34(0.26)$ \\
\hline White-test & $0.93(0.40)$ & $0.94(0.47)$ & $0.86(0.62)$ \\
\hline
\end{tabular}

656 
657 Table 5: Impact on company performance (EBITDA margin) for board membership

\begin{tabular}{|c|c|c|c|}
\hline & Model 4 & Model 5 & Model 6 \\
\hline Intercept & $-2.33^{* *}(0.00)$ & $-6.55^{\star *}(0.02)$ & $-7.06^{*}(0.01)$ \\
\hline Female board share & $0.20(0.86)$ & $-0.30(0.80)$ & $-0.66(0.65)$ \\
\hline Sales & & $0.20(0.11)$ & $0.21(0.12)$ \\
\hline Board dummy & & & $0.09(0.82)$ \\
\hline Product line dummy & & & $0.02(0.95)$ \\
\hline Region dummy & & & $0.18(0.50)$ \\
\hline Adj. R2 & -0.01 & 0.01 & -0.03 \\
\hline F-test & $0.03(0.86)$ & $1.37(0.26)$ & $0.63(0.68)$ \\
\hline White-test & $0.44(0.64)$ & $0.88(0.50)$ & $0.54(0.91)$ \\
\hline
\end{tabular}

659

660 
661 Figure 1. Percentage of females in TMTs among sample companies (excludes zero values).

662 Figure 2. Percentage of female board membership among sample companies (excludes zero values).

663 


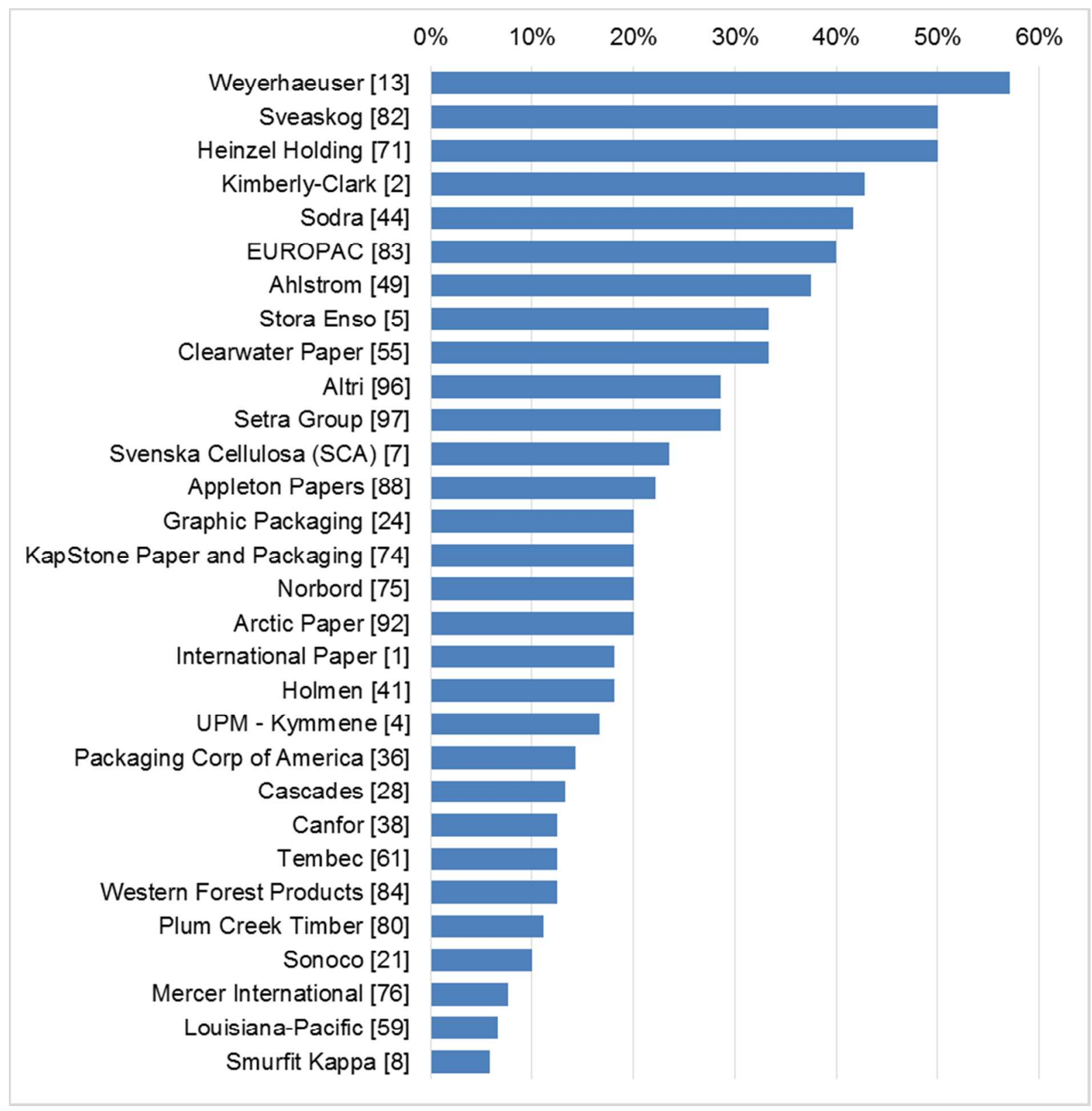

Figure 1. Percentage of females in TMTs among sample companies (excludes zero values). 


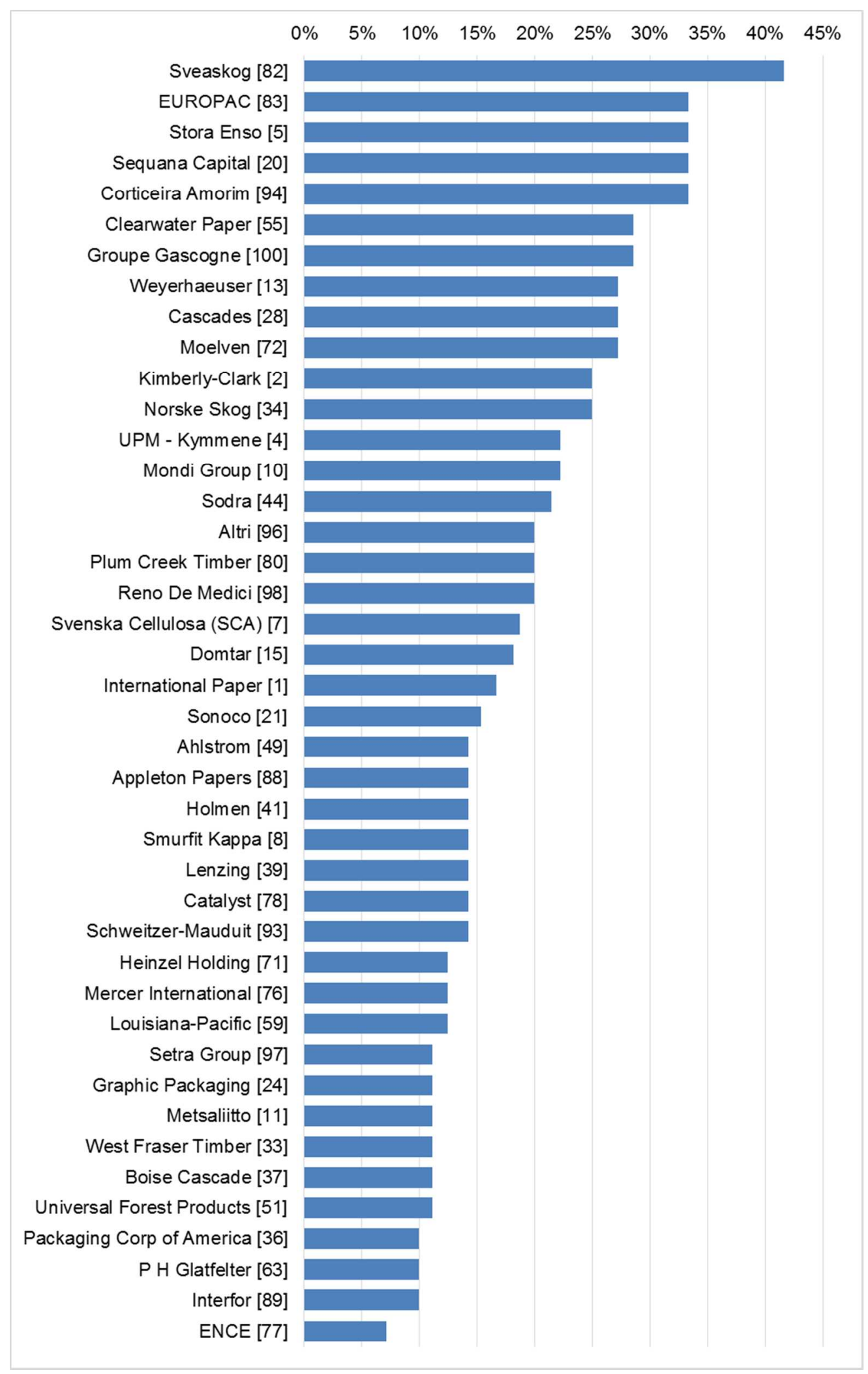

669

Figure 2. Percentage of female board membership among sample companies (excludes zero values). 
' DIRECTIVE OF THE EUROPEAN PARLIAMENT AND OF THE COUNCIL on improving the gender balance among nonexecutive directors of companies listed on stock exchanges and related measures - $\underline{h t t p: / / e u r-l e x . e u r o p a . e u / l e g a l-}$ content/EN/TXT/PDF/?uri=CELEX:52012PC0614\&from=EN 